An ovaluation of the usefulnoss of machine translations produced at the National Physical Laboratory, Teddington, with a summary of the translation methods.

J. MoDaniel, W.I. Price, A.J.M. Szanser, D.M. Yates

\title{
Introduction
}

The machine translation project at the National Physical Laboratory (NPL) has been terminated. It has alrays had as its prime aim a demonstration of the practicability of translation by computer of Russian scientific texts into Bnglish. In order to test how far this aim has been fulfilled and further, to provide evidence to guide a potential agency interested in giving a machine translation service, we have carried out an evaluation experiment on our translations, the conditions of which as far as possible emulated those of a translations service.

The results of this experiment are presented in this paper, together with a summary of the translation methods used. The paper as a whole will thus give an independent presentation of "what methods produced what results". For a comprehensive account of the NPL translation techniques, see reference 1.

\section{Evaluation of Translations}

We have been concerned with the translation of soientifio Russian texts only. In considering how wo might evaluate the results of our work, the context of use of scientific translations imposed two main constraints. Thus, firstly, in the vast majority of cases we would expect readers of translations to be themselves experts in the subject matter of the material translated, i.e. they would be reading the translations because these reflect their main professional responsibilitios. We may then expect that the inherent background knowledge of such readers will ensure a high impetus to their comprehension of translations and help them through syntactic awkwardnesses and multiple-neaning choices. We would also expeot that only a small percentage of these readers would have any competence in Russian. Secondly, the items of translation being read by the above typical readers will normaily be whole information units (journal article, chapter of book, abstract, review, \&c.), and they will have the freedom to ignore unimportant sections of such units and to use sentence or paragraph context (or even remoter references) to help elucidate obscure sections. More specifically, a particular sentence may be poorly trenslated, but because the reader can see that this is not an important sentence or because the context of (hopefully, better-translated) neighbouring sentenoes clarifies its meaning, that sentenos may not affect at all an adequate comprehension of the wole.

Both these constraints are reflected in our evaluation experiment. We ensured that our eveluators were expert in the 
field of the material they were evaluating, and also that they commented on the adequacy of an information unit as a whole, not on individual sentences.

Te have inoluded in this paper (FIG. 2(A)) a short passage from one of the eveluated translations, as the full trenslation is inappropriate for this printed version. However, the full translation will be available for inspection at the presentation of the paper, or the full transletion of another paper can be examined in reference 1.

The evaluation experiment

In order to fulfil the first constraint above, we invited practising soientists to send in Russian papers, reflecting their professional speciality and preferably in the fields of general physics, electronics, or electrical engineering. Some papers resulted from direot invitation, others resulted from an open invitation published in our house journal, "NPL Quarterly". We undertook to send them the machine translations of their papers in return for their comments on how useful the results were. We also obtained second opinions from other specialists in the subjects concerned.

These evaluators were therefore as far as possible typioal of the "customers" of a production un service; in particular they had a personal interest in the subject matter and usually little if any knowledge of Russian.

In all 44 papers were received in response to our invitation; of these 28 were transleted in full ${ }^{1}$. Seven of these were dism regarded for various reasons ${ }^{2}$, and the remaining 21 were inoluded in the evaluation.

38 comments were received on 19 of these 21 papers. Of these two were rejected for vagueness, and three brief comments from one group were treated as one, so in ell the experiment produced 34 comments on 19 papers.

1The other 16 are accounted for as follows: 1 was on a remote subject; 2 were deferred sinoe we had already translated three papers for the same 'customer'; 4 were withdrawn; 3 were translated only in part; and 6 were not reached by the date our computer was scrapped.

$2_{3}$ were on inappropriate subjeots; 2 were translated only by an earlier version of the programs; and 2 were translated too late for inclusion. 
We had decided to give our evaluators a free hand in dism cussing the usefulness to them of translations of this quality. This meant that a soale had to be devised by which their comments could then be graded by us. A scale recently published in the U.S.A. (reference 2) was considered but not odopted since we felt that for our purposes more space should be given to the middlo range of the scale. The following wording was adopted:

8 Fully adequate. Meaning immediately clear, even though not always conventionally expressed.

7

6 Mostly very good. A fow sentences obscure, so that something essential may be lost, but normally clear enough.

5

4 Pair. Takes a good deal of time to extract meaning and even then there is no great confidence in it, resulting in a partial understanding.

3

2 Poor. Could only be useful to somene pr-pared to struggle hard, and even he would often be disappointed.

1

- Useless. Although some semblance of meaning may appear occasionally, it would never be worth the trouble of finding it.

The wording of this scale is not derived on any scientific basis, but it has proved useful in practice, since when four of us came to grade the comments by it independently, there was a good agreement between our merkings. Our four individual ratings for each comment were reduced to a single rating (normelly the mean) after discussion. The range of soores is shown in FIG. 1; the mean soore is 5.6 .

The spread is no doubt due to a real variation in the quality of the translations combined with the prejudices and degrees of patienoe of the evaluators. The lowest scores thus come from impatient professional translators dedling with a poorer-thenaverage text, while the highest ones are perhaps over-enthusiastic supporters dealing with a better-then-average text.

The consensus though, is that there is a real demand for translations of this quality, and this result provides, we feel, ample justification for mounting a broader evaluation exercise, over a wider range of potential readers of such translations, to strengthen, if possible, this verdict and make it possible to

$$
-3-
$$


FIG. 1 Assessment of usefulness of N.P.I. UT output.

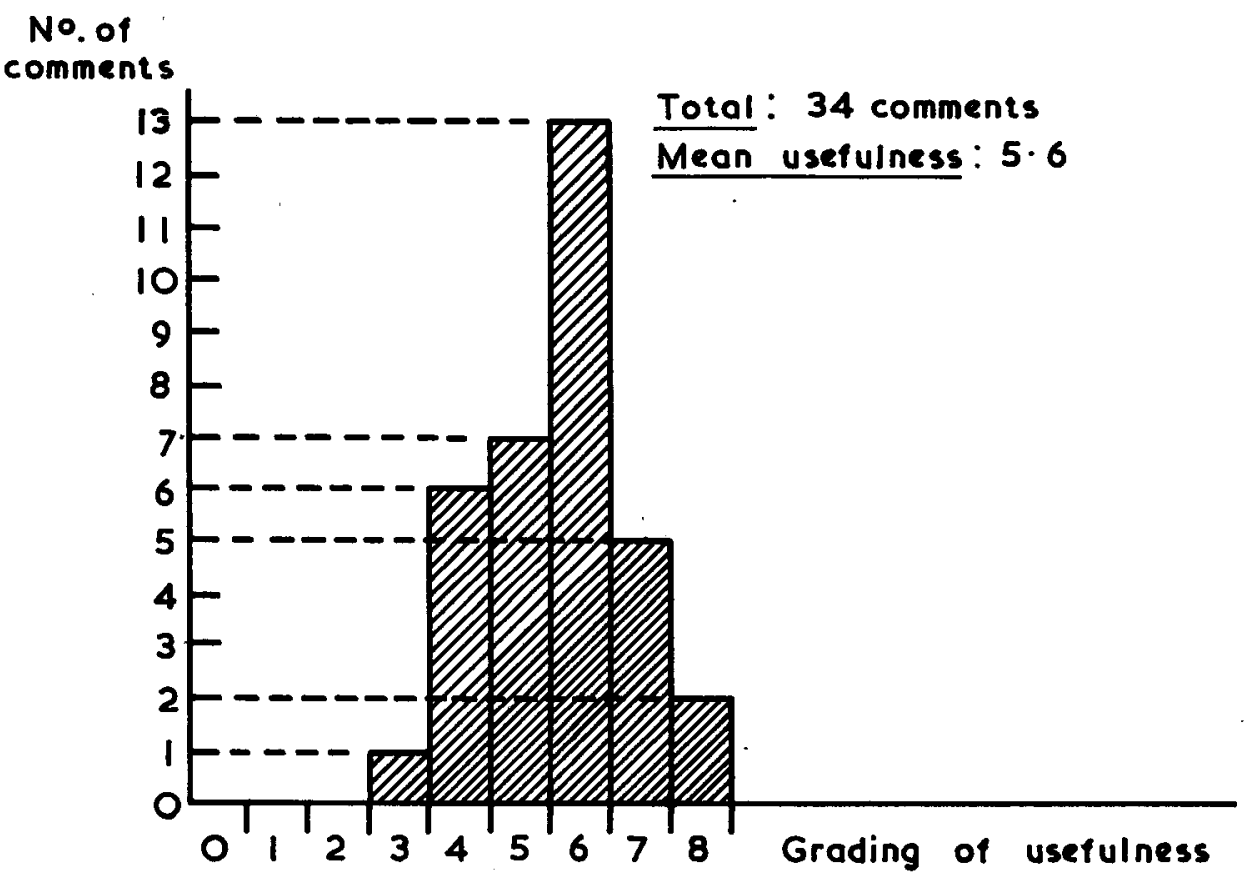


decide on the viability of a produetion machine translation service based on our system.

\section{Eroluators' critioisms}

Apart from the opinions as to the general usefulness of translation, eviluators' comments contained many perticular points of criticism wich deserve discussion. Fe are able to comment ourselves on some of these points from the position of having done considerable development work, just short of full implementation, on techniques designed to overcome the particular translation faults. Full details of this further work are given in reference 1 , and specifio points of reference are given belon.

Most of these oriticisms can be clessified into three groups, concerning respectively: (i) the Inglish equivalents offered, (ii) the syritactic resolution and (iii) the word order.

A frequent critioism concerned missing or inappropriate equivalents. In adition to fully justified remarks of this kind there were elso cases in which the meaning proposed, or preferred by the reader, was uncommon. Its absence from the dictionary was the result of a preferential choice having been made, a compromise between completeness and simplicity. The other alternative, including all possible equivalents, would of course drastically impair readability. The particular solution is often very difficult and can only be achieved to a satisfactory degree after long experience.

In other cases there is no obvious preference and the problem is further aggrevated by the very high frequency of occurrence of the word. Here belong some special clesses, for example all prepositions and some very common words such as $u, a$, and पro - Prepositions can and should be resolved by considering them together with either the governing word or the governed complement (nominal or otherwise) ${ }^{\text {l }}$. (For example, увели чить.. на.., to increase .... by ....'). For the awkward common words specific syntactic sub-routines should be devised. In practically all cases the solution is unique (see reference 1).

Only two evaluators complained about the necessity of selection among two or three equiralents. This is a matter of preference, but it seems to us that for a bona fide reader an additional possibility of meaning (if it is not carried too fer) is more an asset than a disadvantage, even if it impairs to some

${ }^{1}$ On the lines already used for the recognition of idioms, expanded to include non-adjacent words; see below in the summery of methods. 
extent smooth reading ${ }^{1}$. Until a semantio analysis can be echieved, multiple equivalents are bound to stay in $\mathbf{M r}$.

A minor point, but nevertheless worth attention, was to the effect that when multiple equivalents followed each other, the difficulty in understanding increased out of proportion. For example, cлучqeтcя IPU appears as: 'occurs in when the results with

actual meaning is often 'results in'. This was undoubtedly a real problem, which could perhaps be helped by using a longer spece betreen sets of multiple equiralents in the output.

Complaints coneerning un-idiomatic translations (e.8. 'period of rork' instead of 'life-time') would be allayed by more work spent on our idiom list, which contained only about 540 items, whereas 1,500 would be a more realistic figure.

Complaints about inadequate syntactic analysis, leading to obscurities, ambiguities, and wrong resolutions, would have been considerably reduced by a full implementation of the syntactic routines described in reference 1. One of the minor but annoying ambiguities, which had been resolved theoretically, but only partially implemented, was that of adverb/short adjective. Order of clause components wes a frequent subject of criticism; of course they can be re-arranged according to the English usage only after a complete analysis has been made.

Among other things criticized was an inadequate treatment of abbreviations and abbreviated units, some of which were covered by dictionary entries, while others were not, and this led to some misunderstandings. Obviously this again is a matter for a more complete dictionary2. The most difficult case is "nonce" abbreviations (we met, for instance, нейтp. for веитровний and produced 'non-itr.', which helped no one!) Here wo see no prospect of a solution.

Our "anglicizing" routine was critioized (while appreciating the general idea) for unorthodox trassliteration, which made it more difficult to identify the word in a standard dictionary, if necessary 3 . A partial solution may be to exclude certain word

${ }^{1}$ Uuch can be said on this point. Readers, no doubt, will realise how a velvet smoothness of translation may hide many a grievous fault.

2Tith a fow exceptions, however. Thus 'B' may be very troublesome, as regards the choice between the preposition and the abbreviated unit ("volt"), without a special syntactic subroutine.

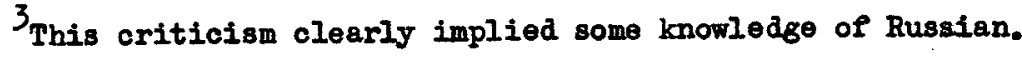


classes, e.g. acronymic abbreviations, which are obviously not suitable objects for the routine (they can be automatically recognized as clusters of capital letters). Also, in our prefix-reoognizing routine there is an inherent denger that a "not-in-dictionary" word may have a part of the stem identical with an accepted prefix. This applies in particular to short prefixes, like 8 - , in the above example of Beftrp.. There is no general way of dealing with such words. The best solution, in respect of both routines, seems to be, howerer, to include in the output both the original (in Cyrillic, if possible) and the synthetic equivalent for all "not-in-dictionary" words.

A few comments contained bouquets rather than brickbats. One evaluator commented thet the translation became easier to read as he got used to the unusual 'style'; and another found an instance where $a$ slip in the published human translation had reversed the intended meaning; our version of the passage, while not perfect by any means, was certainly not misleading in this way.

Pinally, severel evaluators commented that machine translations would need to show advantages in cost and speed over human translations in order for them to be attractive as well as acceptable, and these are indeed criterie that we would ourselves put forward without fear of contradiction. We have not included a study of cost and speed within this evaluation experiment, as we do not have the market data to prepare a translation service speoification that we could then refer such a study to. However it is evident that our machine equivalent of the human translator i.e. input punching, machine translation and output printing (with no human post-editor) will show a clear advantage on both these points. It would be essential to fit this component, though, into an overall translation system which wes specified carefully to fit the translation market.

In FIG. 2(A) is shown a facsimile of a short passage of our machine translation into English of a Russian text on electric furnaces, completely non-post-edited. The vertical lists of two or three words are to be read as alternative Bnglish correspondents for the Russian word in that position. FIG 2(B) is a facsimile of the original Russian text.

\section{A summary of the translation methods}

\section{Text Preparation and Dictionary Look-up}

The dictionary used in the NPL machine translation system was developed from an early version of the Harvard Russian-English computer dictionary. Our dictionary contains about 18,000 entries (with additional cross-reference entries) covering the fields of electronics and electrical engineering.

We chose to organize the diotionary on a stem and suffix 
IIG. 2(A) English maohino translation

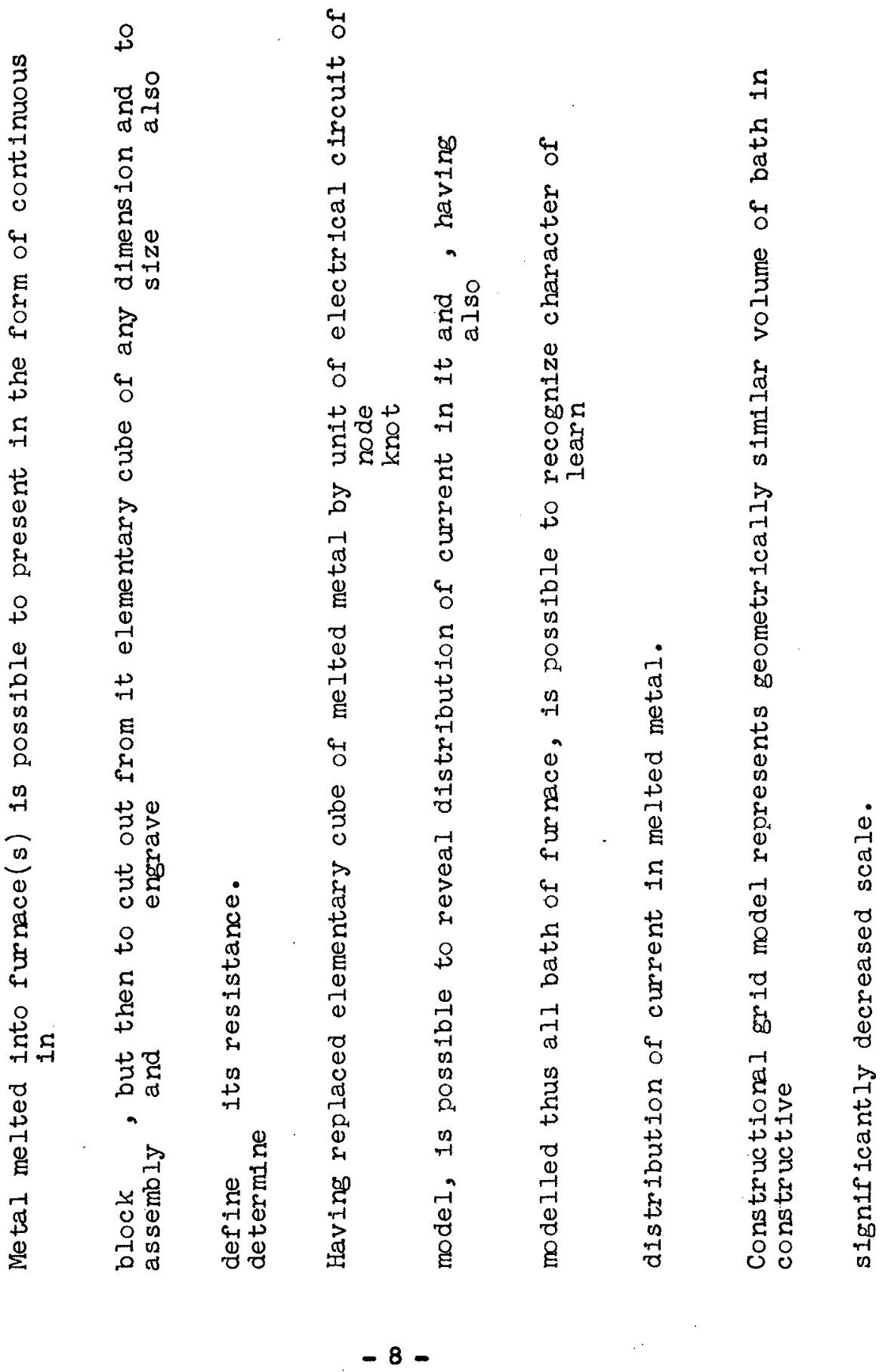


FIG. 2(B) Russian original text.

\section{распределения әлектрического тока . ванне расплавленного металла}

(амдидам "техн. каук, доц. А. Н. ЛЕУUКН

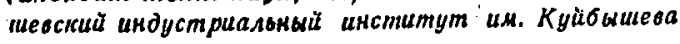

гектрического тоической печи, как ольшое теоретіlче: Поттому вопросы, ісояна [Л. 1], трензучення. Особуго зание ' распределе. ым металлом. Вы. анне печн настоямплексного реше- перемешивания еленне характера дать более рацио$l$ и конструкцию чнсле и размеше$x$ печах, правильiн электромагнитD. В настояшей ся применнтельно

авленном металле от формы ванны, 'ружения электролектрический ток i Характернзуется уравненнем Ла:

$$
=0
$$

једы; кого поля.

тока через масзается действием внным точкам на ть вектор плотно:-

зктрическая цепь лення тока в сплошных проводящих средах при меня отся три внда моделей: проводящие пластины, или листы, электролитинеские ванны и решетки, нли сетки. Нопользованне решеток, Нли сеток, дз сопротнвлений имеет бесспорное пренмущество по сравнению с остальнымн опособами, так как позволяет нелосредственно исследовать распределение токов в модели.

Для осуществления подобия физических процессов объекта и моделн иеобходнм лравнльный выбор к.ритериев подобия. Необходнмые н доста. точные условия подобия физических явлений устанавливаются третьей теоремой подобия, доказан. ной еше в 1930 г. М. В. Кирличевым.

Обший критернй подобия,

$$
k=l \sqrt{\omega \gamma \mu}
$$

где $l$ - лннейные размеры;

$\omega-$ - угловая частота;

$\mu$ - магнитная проннцаемость

$\gamma$-удельная проводимость.

При равенстве $\omega$ и $\mu$ обчекта и модели наио̆олее фажсными критериями подобия являгтся размеры и пооводимость материала сетки нодели.

расплавленный в печи металл можно представить в виде сплошного блока, а затем вырезать из него элементарный куб́ любого размера и определить его оопротнвленне. Заменив элементарный куб расллавленного металла узлом электрической цопи модели, можино выявить распределение тока в нем и, смоделиравав таким образом всіо ванну печи, можно узнать характер распределения тока в 'расплавленном металле.

Қонструктнвно сеточная модель представляет собой геометрически подобный объем ванны в значительно уменьшенном масштабе.

Сопротивление элементарных кубнков металла имнтруется сопротивленнем соедннительных проводов - шага ячеек модели. War cerki зависит от геометрических размеров объекта н модели и, следовательно, от общего количества ячеек модели. Тачность моделирования будет.тем выше, чем больше чнсло ячеек. Однако слишком оольшое число ячеек ухудшает условия измерения и јвелимиает габариты модели и материа.эblib затраты ia неe. 
basis, in which each entry contains a Russian stem togethor with a coded list of suffixes whioh can combine with the stem. This gave far fewer ontries than would have boen found in a fullform dictionary covering the same words. Fach entry contains grammatical data and English equivalents of the Russian.

The stem and suffix organisation demanded that we create a system of splitting Russian words consistently into sten and suffix, fully desoribed in Davies \& Day, (1961). The split is made at the point determined by the maximum number of letters which together form a Russian suffix or string of suffixes. The maximum split technique sometimes oauses too many letters to be treated as part of the suffix, in other words, the split is made too early in the word. Such words are provided with a oross-reference dictionary entry which directs the searoh to an entry in which the full information for the word is contained.

The diotionary is recorded on two reels of magnetic tape, the entries being arranged in alphabetical order. Time of consultation of the full dictionary is from 12 minutes upwards, depending on the number of entries being sought.

A text for translation is first punched on cards by an operator who recognizes Cyrillic characters, though she cannot read Russian. Symbols, punctuation marks and Cyrillio characters are represented by one card column per character. Provision is made for indicating a space to be left in the text where an equation or group of symbols occurs. These will be inserted in the translation by hand. The cards are treated as a continuous medium, card boundaries being ignored. By this means quite a long paper can be encoded on a relatively small number of punohed cards.

The text, now on cards, is fed into the computer. The first computing process gives a serial number to each text word and then splits the word into stem and suffix. When all text words have been subjected to this process, they are then sorted into alphabetical order. This is essential for optimum speed of look-up in our serially organised dictionary.

The next programme in the translation sequence, the lookup programme, scans sinultaneously through the dictionary and the sorted text, seeking dictionary entries corresponding to the text words. The programme allows for the occurrence of stem homographs and for the correct handling of cross-reference entries. The output of the progremme (which we call, following Harvard, the augmented text) consists of the text words each with the relevant dictionary entries appended.

Heving obtained a set of eugmented text entries, the translation sequence then sorts these back to text order, using the text serial number originally allocated to each text word. 
The result of this series of operations is a text in the original order, with dictionary entries appended to all but a few of the items. Symbols and punctuation marks do not, of course, have corresponding dictionary entries, and there may be words in the text which are not represented in the computer dictionary. The latter are given special treatment in the syntectic routines and translation output.

Provision is made in the dictionary for the representation of idioms, using a method analogous to that used in an ordinary dictionary. A "key word" is chosen in the idiom (normally the least frequently occurring word), the idiom being represented in the dictionary entry of the key word. The representation includes a list of the component words of the idiom, using which the presence of en idiomatio text word sequenoe can be detected before attempting any syntactio operations on the augmented text. The dictionary entry including the idiom contains the preferred Bnglish equivalent. The dictionary includes coding for 540 idioms.

Words not represented in the dictionary are given special treatment, as mentioned above. All text words which commence with one of a set of 137 Russien prefixes are looked up both with and without prefix. If the prefixed form does not occur in the dictionary, but the unprefixed form is found, then the entry for the unprefixed form is included in the augmented text, coupled with an English rendering of the Russian prefix. Despite this provision, some text words will not intersect with the dietionary. Por these an attempt is mado to determine part of speech, case, number, etc., by an inspection of grammatical and derivetional suffixes. In the transiation output the stem of the not-in-dictionary word is transliterated, aiming to anglicize as far as possible the original word. A derivational suffix is given its English equivalent in the output rendering; any prefix that was recognised is also given its English rendering.

From an augmented text produced by the foregoing procedures it would be a simple mechanical process to achieve a word-forword "translation". We felt this was not worthwhile, as the application of relatively simple rules of grammar and syntex greatly enhance intelligibility of such a product.

\section{Russian Analysis Algorlthm}

In the first place we designed and implemented a systen of noun blooking and a simple predicate analysis. The results obtained were not by any means ideal, but we were encouraged to extend and refine our syntectic processes. In our first attempt the funotions of Russien analysis and English synthesis were olosely interwoven. As our syntactic procedures were extended to cover more features it beceme evident that it was essential to separate the functions of analysis and synthesis. In order to make this possible the linguistic model, described 
in Yates (this conference) was dereloped. The model permits the analysis routines to express the Russian syntax as far as necessary and facilitates a transformation to the corresponding Riglish sentence structure.

The analysis routines operate in a succession of passes through each sentence, defined by major punctuation mark boundaries (full stop, question mark and semi-colon)

The functions of the successive pásses are as follows:

1. A preliminary pass which estabiliohes from the augmented text the terminal element for each discrete member of the sentence. Punctuation marks are indicated in the elements for preoeding or following sentence items, eccording to a set of formal rules.

2. A pass whose prime concern is the determination of nominal struotures, $i, \theta$. nouns and words with which they are closely connected, such as adjectires or prepositions.

3. A pess which establishes links between adjacent nominal structures; the linked elements include genitive qualifiers and prepositional group qualifiers.

4. A pess which searches for potential coordinating conjunctions and examines the sentence elements or structures separated by suoh conjunotions, setting up coordinate groups where appropriate.

5. A pass whioh ireates simple predicate structures, searching for words with a verb role and then locating adjacent sentence elements or structures acting as verb adjuncts.

6. A pass whose function is to examine the role of some of the more "difficult" words such as the verb 6 HTs and its infleoted forms, and the personel/possessive pronouns ero, ee and $\mathrm{nx}$

A full description of these analysis routines is given in reference 1. In the present paper we shall take a Russian sentence and note the effeot of each analysis pass on it.

The Russian sentenoe reads:

Bexma i qервm места вапricz rpanin.

The first analysis pass is not of particular interest in the present context. Suffice it to say that a system of referenoe addresses is set up which permits the scanning of the sentence whilst its structure is in an incomplete state. 
The state of the sentence diagram after the second pass has been completed is:-

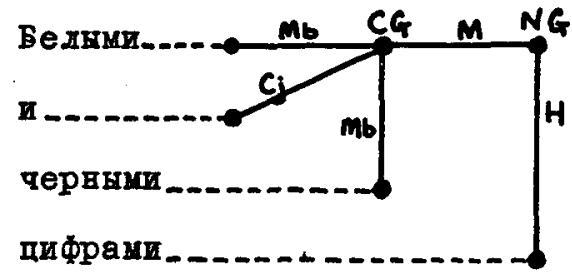

$\mathbf{n}$

cтpeskase

пока 8авH

xecta

ganncI

травиц.

One noun group has been formed, of which the modifier is a coordinate group of adjectives. Fach adjective is marked as a member in the coordinate group, which itself assumes the properties of an adjective. 
The third analysis pass has the function of creating genitive and prepositional links. Only the former are concerned in our sample sentence:-

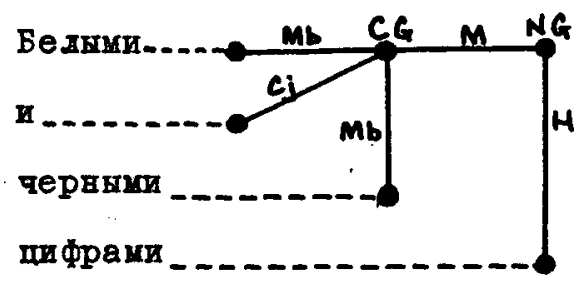

a

cтpesraxu

потававম

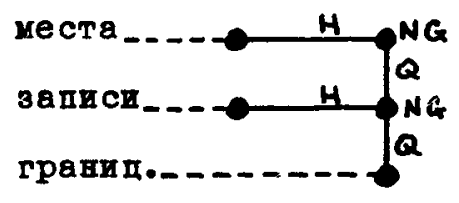

Were there any prepositional groups following nouns, then the prepositional groups would also be linked in as qualiflers. 
The second analysis pass ignored all conjunctions which did not occur explioitly within simple noun groups (i. $\theta$. groups with a single noun as head). The fourth pass, however, seeks to join to existing noun groups any other nouns linked by coordinating conjunctions:-

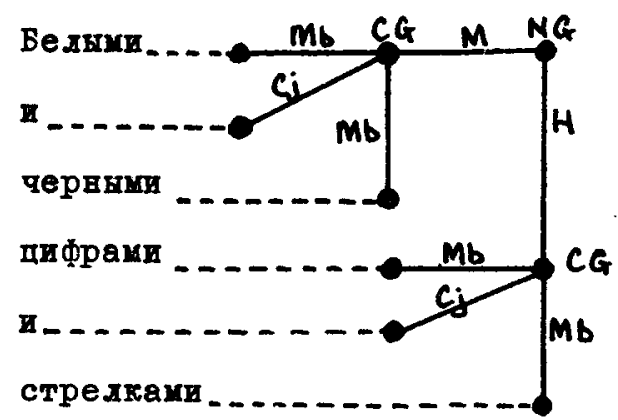

пока8авн

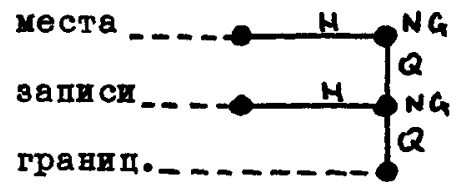

In adaition the pass groups together in coordinate groups any similar words joined by coordinating conjunctions, whatever their pert of speech. Intervening punctuation prevents the formation of coordinate groups. The coordinate group, when formed, is given the grammatical significance of its component parts. 
The fifth analysis pass has little effeot on our sample sentence. The plural, short form participle is the single "verb" member of its verb group:-

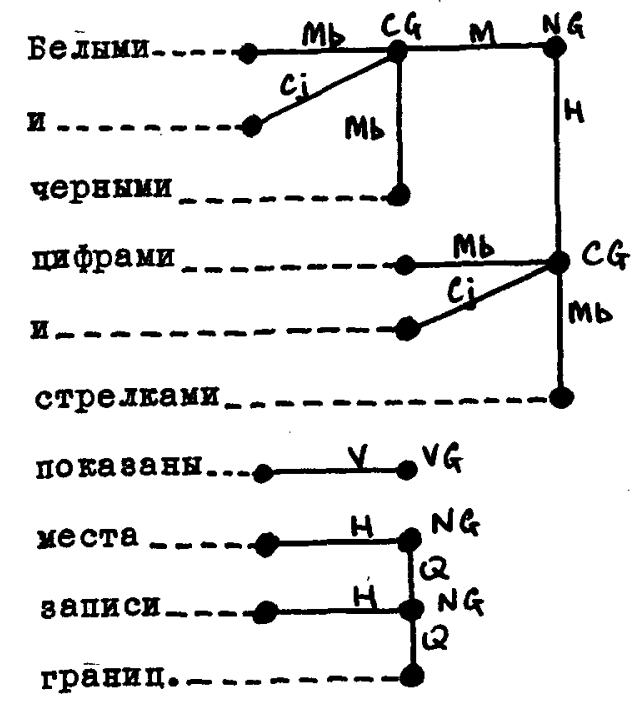

Were there adjacent adverbs or prepositional groups, these would be included in the verb group with the role of adjunct. The fifth pass also has provision for negative and conditional predicate structures.

The function of the sixth pass is to try and resolve the roles of certain more "difficult" words. (No instances occur in the sample sentence). For example, if one of the ambiguous personal/possessive pronouns is encountered, a check is made to see whether the folloring sentence element is nominal. If it is, then the pronoun is joined in the element as a modifier, and the pronoun is treated as possessive. Forms of the verb 6 HTB wich were not covered by the provisions of pass five, are also included in the sixth pass.

Having completed the sixth pass, no further anelysis of the Russian sentence is undertaken. The sentence structure 
delineated by the analysis passes is not complete, since no attempt is mede to set up a clause structure. However, in order to facilitate the task of the synthesis prooedure, all the separate group structures (and any remaining separate elements) are arbitrarily conneoted together in one or more higher groups, presenting the appearance of a unifiod whole to the synthesis stage.

On the other hand if further analysis passes were applied, partioularly with reference to clause delimitation (for example, see Appendix 1 of referenoe 1), then the sample sentence would eppear as:-

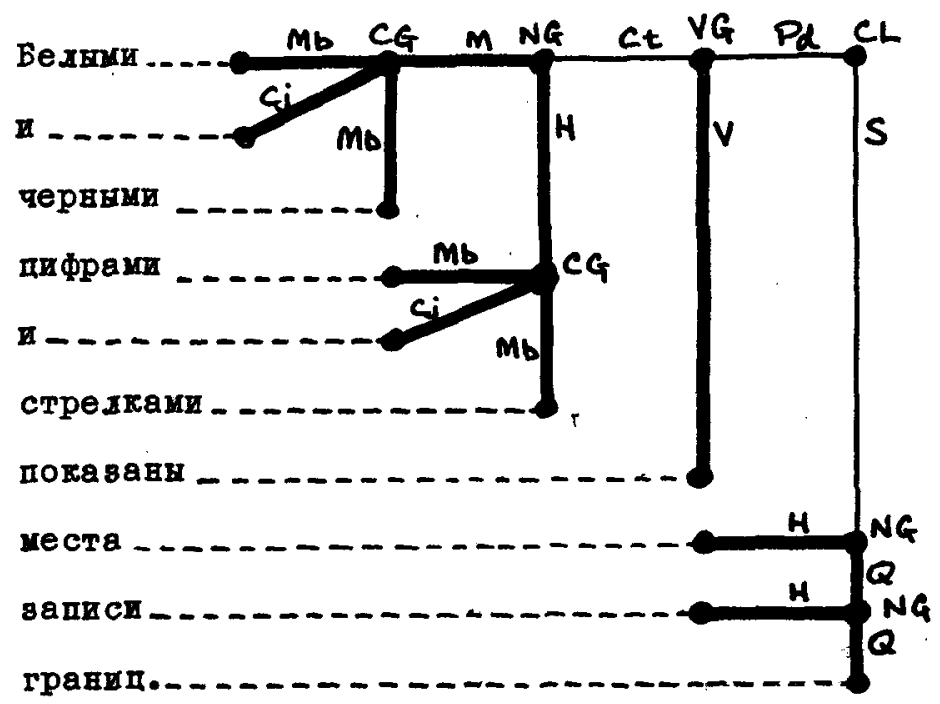

Thick lines indicate those connections which our analysis routines have created, and the thin lines indicate those which rould befm created by additional routines.

The translation sequence is completed by an Bnglish synthesis process. This determines re-orderings, insertions, infleotions and seleotions of Finglish equivalents, and, finally, the format of the printed output, produced by the computer on paper tape and printed on a flexxomriter. This prooess is described in the companion paper, which also includes an account of the descriptive model mentioned above. 


\section{References}

1. MODANIKT, J., DAY, A. $\mathbf{H}_{0}$, PRICB, W. $\boldsymbol{L}_{0}$, SZANSER, A.J., WHETAN, $S$. and YATBS, D.M. "Translation of Russian soientifio texts into Bnglish by computer - a final report" . National Physioal Laboratory, Autonomics Division report 35, June 1967.

2. National Academy of Sclences/National Research Counoil, "Language and machines; computers in translation and linguistics". 1966.

3. DAVIES, D.W. and DAY, A.Y. "A technique for consistent splitting of Russian words". Proc. Intl. Conf. on Machine Translation of Languages and Applied Language Analysis, H.M. Stationery Office, 1962, 1, 343-362.

4. YATES, D.M. "A computer model for Russian gramatical description, and a method of English synthesis in machine translation". This Conferenoe.

The work described above was carried out at the National Physical Iaboratory. 